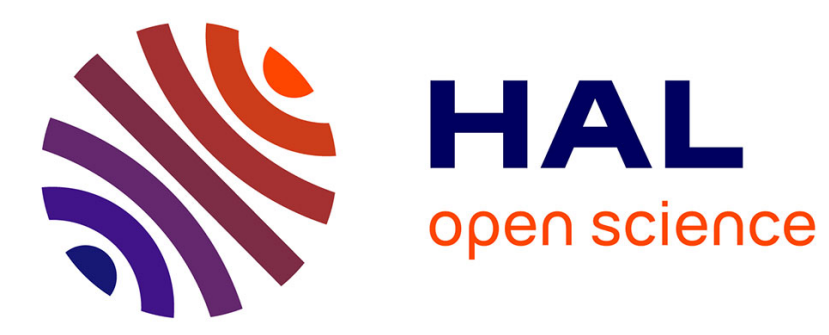

\title{
Hydrological modelling for meso-scale catchments using globally available data
}

A. Gafurov, J. Götzinger, A. Bárdossy

\section{To cite this version:}

A. Gafurov, J. Götzinger, A. Bárdossy. Hydrological modelling for meso-scale catchments using globally available data. Hydrology and Earth System Sciences Discussions, 2006, 3 (4), pp.2209-2242.

hal-00298752

\section{HAL Id: hal-00298752 \\ https://hal.science/hal-00298752}

Submitted on 11 Aug 2006

HAL is a multi-disciplinary open access archive for the deposit and dissemination of scientific research documents, whether they are published or not. The documents may come from teaching and research institutions in France or abroad, or from public or private research centers.
L'archive ouverte pluridisciplinaire HAL, est destinée au dépôt et à la diffusion de documents scientifiques de niveau recherche, publiés ou non, émanant des établissements d'enseignement et de recherche français ou étrangers, des laboratoires publics ou privés. 
Hydrol. Earth Syst. Sci. Discuss., 3, 2209-2242, 2006 www.hydrol-earth-syst-sci-discuss.net/3/2209/2006/

(C) Author(s) 2006. This work is licensed under a Creative Commons License.
Hydrology and Earth System Sciences Discussions

Papers published in Hydrology and Earth System Sciences Discussions are under open-access review for the journal Hydrology and Earth System Sciences

\section{Hydrological modelling for meso-scale catchments using globally available data}

\section{A. Gafurov, J. Götzinger, and A. Bárdossy}

Institute of Hydraulic Engineering, Department of Hydrology and Geohydrology, University of Stuttgart, Pfaffenwaldring 61, 70550 Stuttgart, Germany

Received: 20 April 2006 - Accepted: 28 April 2006 - Published: 11 August 2006

Correspondence to: A. Gafurov (abror.gafurov@iws.uni-stuttgart.de)

\section{HESSD}

3, 2209-2242, 2006

Hydrological modelling using globally available data

\section{A. Gafurov et al.}

\section{Title Page}

Abstract

Conclusions

Tables

14

4

Back
Introduction

References

Figures

$\rightarrow$

Close
Full Screen / Esc

Printer-friendly Version

Interactive Discussion 


\section{Abstract}

This study focuses on modelling water balances for catchments with limited data availability. The objective was to use globally available data for water balance modelling of meso-scale catchments. The study is carried out in two catchments; one having 5 enough data for the performance check of the model and the other with very few data for model validation. Globally available meteorological and geographical data is used for the basic model inputs. Dissaggregation of the global data, both spatially and temporally, was conducted to distribute the available data across the watershed and to attain higher resolution input data for the model. In addition, a glacier module was de(n) stitute of Hydraulic Engineering at the University of Stuttgart is applied. The outcomes of the modelling provide noteworthy results for both catchments that can be used in water resources planning and management issues. Moreover, the research presents the potential for modelling water balances using predominantly globally available data and proposes appropriate disaggregation methods for global data usage.

\section{Introduction}

Water has been identified as one of the key issues in reaching the Millennium Development Goals (UNDP, 2003). With water availability issues increasing, these goals can only be achieved by improving the management of water resources. Good management is central for the sustainable use of water resources around the world. The most problematic regions in terms of water availability are found in the Savannah and Steppe zone due to high evaporative demands and land degradation (Falkenmark, 2005). Many tools are currently being developed for the assessment of the effects of changing climate and land use on water resources (Alcamo et al., 2003). Hydrological models are such tools, supporting water resources management and planning issues. They have recently been used to assess regional discharges and also climate change
HESSD

3, 2209-2242, 2006

Hydrological modelling using globally available data

A. Gafurov et al.

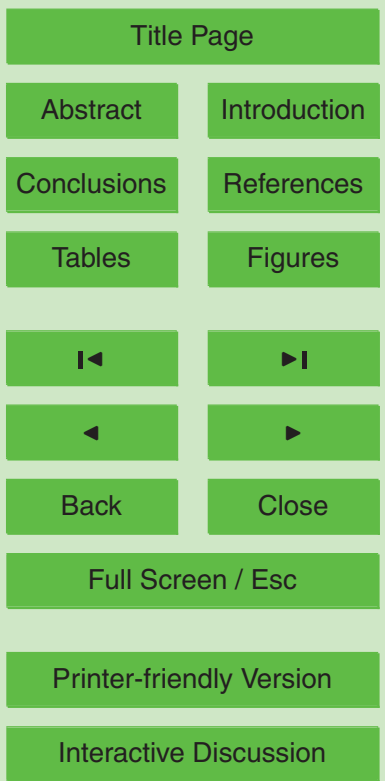

EGU 
issues. Performance of these models depends on the availability of input data. Unfortunately, in many regions of the world very few locally-derived data are available which prevents the use of complex hydrological models. Among other regions, Africa, Central Asia and South-East Asia are known as data sparse regions where the ground 5 based observation network is declining (Schertzer et al., 2002). Unavailability of required data for modelling has lead to the IAHS PUB initiative focusing on hydrological modelling in areas with few available data or data in lower resolution. (Sivapalan et al., 2003). The challenge is modelling water balances for data limited conditions. This paper presents a method to model daily river discharges in meso-scale catchments 10 using globally available data.

In the past, there have been considerable advances in archiving historical data globally and even simulating or reanalysing them for the whole world. Interpolated monthly values of precipitation from 1986 on are available worldwide at a spatial resolution of $1^{\circ}$ from the Global Precipitation Climatology Centre (GPCC) (Rudolf et al., 2003). Daily 15 precipitation simulations (reanalyses) are available worldwide from the National Centre for Environmental Prediction (NCEP) on a Gaussian grid system (Kalnay, et al., 1996). Unfortunately the bias in those datasets is too large to be used in hydrological models. In order to eliminate large bias in datasets the first initiative would be to combine the two data sources to create a time series with small bias and a realistic daily distribution that is suitable as input for hydrological models with daily time steps. Daily observed temperature station data are globally available from the Global Historical Climatology Network (GHCN) (Nelson and Burtis, 1995).

The data mentioned above are those primarily adopted in this study. A lapse rate method is introduced to interpolate the station data with consideration of the respective catchment topography. This methodology has been applied in two test catchments: The Neckar catchment in south Germany, for which there is very detailed observation data available and where the interpolated temperature data can be compared against observations, and the Chirchik catchment in Uzbekistan where more detailed input data are lacking.

\section{HESSD}

3, 2209-2242, 2006

\section{Hydrological modelling using globally available data}

\section{A. Gafurov et al.}

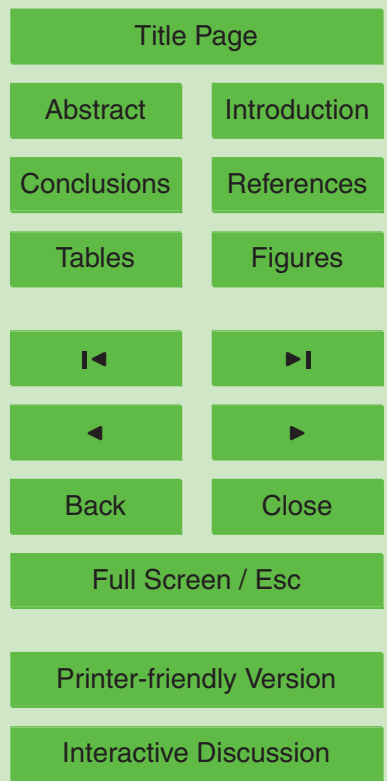


Using the disaggregated and interpolated data the model is ultimately run with daily resolution but calibrated against monthly observations. A comparison of observed and modelled daily discharge in the Neckar basin show that the distribution of discharges can be very well reproduced and monthly modelled discharges in both catchments

5 show that the modelling method is a good tool for the aforementioned problem. The HBV-IWS model is used in this study and also enhanced for the Chirchik basin according to its geography and climate conditions.

\section{Study area}

The Neckar basin in Germany and the Chirchik basin in Uzbekistan are the study 10 areas in this research. The Neckar basin extends from latitude $47^{\circ} 40^{\prime} \mathrm{N}$ to $49^{\circ} 50^{\prime} \mathrm{N}$ and longitude $7^{\circ} 50^{\prime} \mathrm{E}$ to $10^{\circ} 30^{\prime} \mathrm{E}$ (Fig. 1). The area of the basin covers approximately $14000 \mathrm{~km}^{2}$. The elevation in the catchment varies from $1030 \mathrm{~m}$ a.s.l. at its source in the Swabian Alb mountains to $245 \mathrm{~m}$ a.s.l. at the catchment outlet. Average annual precipitation is $950 \mathrm{~mm}$, ranging from $750 \mathrm{~mm}$ in the lower part to $1600 \mathrm{~mm}$ close to 15 Swabian Alb and the average daily temperature is $8.7^{\circ} \mathrm{C}$. Short period snowfalls occur in winter, but do not persist very long.

The Chirchik basin extends from latitude $40^{\circ} 10^{\prime} \mathrm{N}$ to $42^{\circ} 0^{\prime} \mathrm{N}$ and longitude $70^{\circ} 10^{\prime} \mathrm{E}$ to $72^{\circ} 30^{\prime} \mathrm{E}$ (Fig. 2). The area of the basin covers $15300 \mathrm{~km}^{2}$. Elevation in this catchment ranges from over $4000 \mathrm{~m}$ a.s.l. at the mountain ridges in the eastern part of 20

the catchment to $400 \mathrm{~m}$ a.s.I. at the confluence of the Chirchik with the Syrdarya. The catchment is principally located in eastern Uzbekistan, however small parts of it belong to Kazakhstan and Kyrgyzstan. Average long term precipitation is approximately $350 \mathrm{~mm} /$ year. The temperatures vary greatly from summer to winter. The mean monthly temperature in summer exceeds $20^{\circ} \mathrm{C}$, whereas it is sometimes below $-12^{\circ} \mathrm{C}$ 25

of Chirchik and this is the source of the aforementioned glaciers. The Chirchik River discharge comprises both rainfall and snowmelt. Snowfall occurs in winter and rainfall

HESSD

3, 2209-2242, 2006

\section{A. Gafurov et al.}

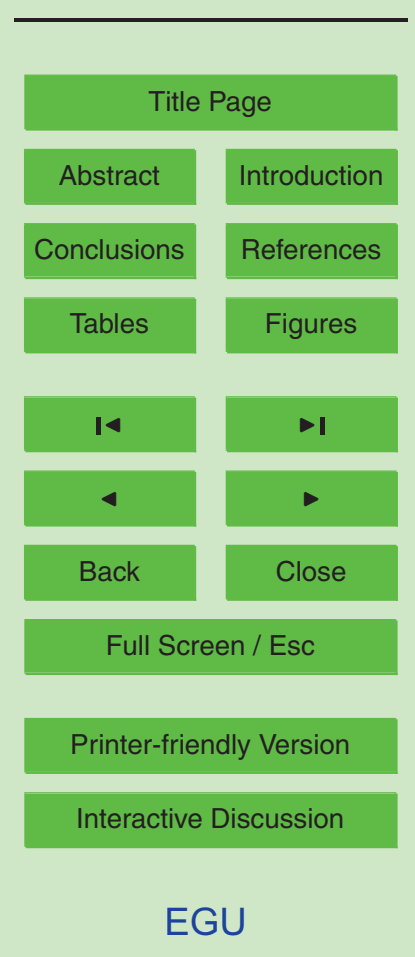




\section{Data collection}

One objective of this research is to assess the reliability of the model with the use of globally available data for water balance modelling in meso-scale catchments. For hy5 drological modelling, the meteorological data (precipitation and temperature) are most important. Interpolated monthly precipitation data from 1986 on were obtained from the GPCC, which is offered by the German Weather Service (DWD) for the whole globe with a spatial resolution of $1^{\circ}$. Daily precipitation simulations (reanalyses) are obtained from NCEP in a Gaussian grid (T62 with $94 \times 192$ points for the globe surface - ap10 proximately $1.88^{\circ} \times 1.92^{\circ}$ grid cells). The two data sources were combined to create a daily distribution time series to be used as input for the model. The GPCC data is interpolated monthly observed data and has a fine spatial resolution and NCEP data derives from the reanalysis of historical data and has a daily temporal resolution. New daily precipitation data was created from GPCC and NCEP adopting the variability of

$$
P_{\text {dis }}=\frac{P_{n d} \times P_{g}}{P_{n m}}
$$

Where:

$P_{\text {dis }}-$ disaggregated precipitation, $P_{n d}-$ daily NCEP precipitation, $P_{g}-$ monthly GPCC precipitation, $P_{n m}$ - aggregated monthly NCEP precipitation, $P_{n m}$ was obtained by aggregating daily data to monthly taking the arithmetic mean monthly value. This calculation was conducted for each $1 \mathrm{~km}^{2}$ grid cell over the whole Neckar and Chirchik Basins. The resulting precipitation data have a daily temporal resolution and a spatial resolution of $1000 \mathrm{~m}$.

Daily temperature data for this study was available from the GHCN through KNMI
(Royal Netherlands Meteorological Institute). The GHCN provides observed historical
3, 2209-2242, 2006

Hydrological modelling using globally available data

A. Gafurov et al.

\section{Title Page}

Abstract Introduction

Conclusions

Tables References Figures

14

4

Back

Close

Full Screen / Esc

Printer-friendly Version

Interactive Discussion

EGU 
station data with a daily time step and some observations for Chirchik and Neckar were available. A lapse rate method is used to interpolate the station data for other regions. The lapse rate for both catchments was estimated using the available station data and topography. For the Neckar basin, a $7.8^{\circ} \mathrm{C}$ per $1000 \mathrm{~m}$ lapse rate was found to be most 5 appropriate to estimate the temperature in other regions. The lapse rate estimation for the Chirchik basin based on available short term temperature data showed that $6.8^{\circ} \mathrm{C}$ per $1000 \mathrm{~m}$ is most appropriate for the temperature interpolation at other sites in the Chirchik basin. Figures 3 and 4 are examples of temperature comparison at Neckar basin.

10 For temperature, the simple lapse rate method worked well for interpolated data. The interpolation of precipitation data is much more complex because topography plays a more significant role. More details regarding the precipitation interpolation in the Chirchik basin can be found in Sect. 7.

The Digital Elevation Model (DEM) that was used for the respective model setup of 15 the catchments and was available from the United States Geological Survey (USGS) has a spatial resolution of $80 \mathrm{~m}$.

The land use map (LANDSAT93) of Baden-Württemberg was used for the Neckar basin. Land use information for the Chirchik basin was unavailable however the whole upper Chirchik is assumed to be agricultural fields, based on the author's experience of the region. Although this does not offer very accurate information, it is assumed to be acceptable for the model.

A soil map for the Neckar catchment (BÜK200; scale 1:200 000) was used to identify dominant soil types in the catchment. A soil map for Chirchik basin was available from the Scientific Information Centre (SIC), Interstate Commission for Water Coordination

\section{HESSD}

3, 2209-2242, 2006

Hydrological modelling using globally available data

\section{A. Gafurov et al.}

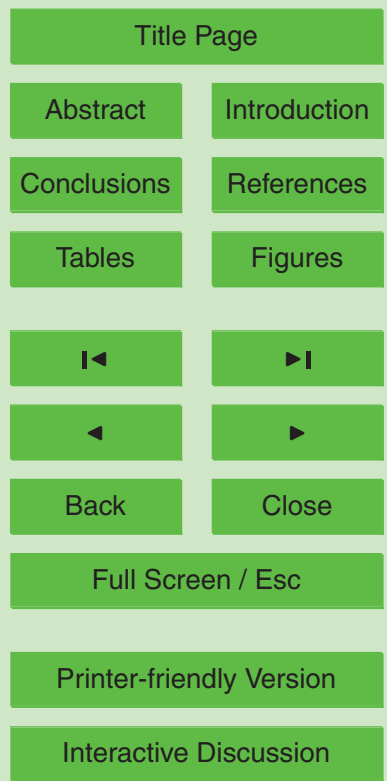




\section{HBV-IWS model}

The HBV-IWS model, developed at the Department of Hydraulic Engineering of the University of Stuttgart was applied. It is based on the HBV model from the Swedish Meteorological and Hydrological Institute (SMHI) after Bergström (1995). It is a semi5 distributed, conceptual hydrological model with precipitation, air temperature, estimated potential evapotranspiration, soil information and land use input data requirements. The HBV-IWS model consists of a snow module, a soil moisture and runoff generation routine, an evapotranspiration routine and a discharge response routine.

The snow model uses the degree day method to quantify snowmelt and snow accu10 mulation. The concept is as follows:

$$
\begin{aligned}
& \begin{array}{l}
\text { MELT }=\text { Min }\left(\text { Snow; } C_{\text {melt }} \times(T-T T)\right) \\
\text { Snow }=\text { Snow-MELT }
\end{array} \\
& \left.\begin{array}{l}
\text { Snow }=\text { Snow }+P \\
\text { MELT }=0
\end{array}\right\} \text { if } \quad T>T T \\
& \text { if } \quad T<T T
\end{aligned}
$$

HESSD

3, 2209-2242, 2006

Hydrological modelling using globally available data

\section{A. Gafurov et al.}

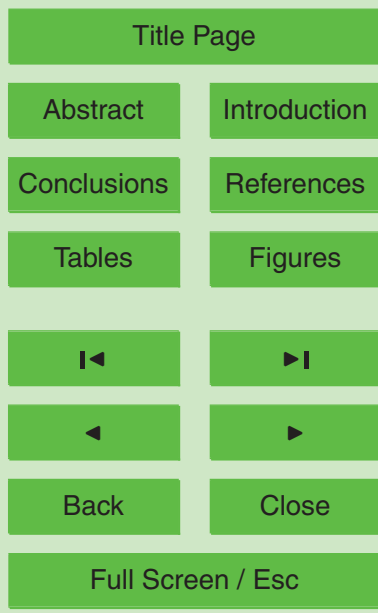

Printer-friendly Version

Interactive Discussion

$$
\begin{array}{ll}
\text { MELT } & : \text { amount of snowmelt per day }[\mathrm{mm} / \text { day }] \\
\text { SNOW } & : \text { snow accumulation }[\mathrm{mm}] \\
T & : \text { air temperature }\left[{ }^{\circ} \mathrm{C}\right] \\
T T & : \text { threshold tempoerature }\left[{ }^{\circ} \mathrm{C}\right] \\
C_{\text {melt }} & : \text { degree day factor }\left[\mathrm{mm} /{ }^{\circ} \mathrm{C} / \text { day }\right]
\end{array}
$$

15 In the soil moisture and runoff generation routine the precipitation is divided into two parts; one reduces the soil moisture deficit and the other becomes the effective precipitation, which contributes to runoff generation. New rainfall first contributes to soil moisture and only when the field capacity of the soil is reached, does all water contribute to direct runoff.

The evapotranspiration module calculates actual evapotranspiration from the perma- 
nent wilting point of the soil, the soil moisture of the previous time step and the potential evapotranspiration. Potential evapotranspiration of the region has to be calculated outside of the model and can be done using many available methods. Actual evapotranspiration is equal to potential evapotranspiration if the soil moisture is larger than 5 the permanent wilting point. Elsewhere it changes according to the following formula:

$E T_{A}=P E_{A} \times \frac{S M}{P W P}$

where:

$S M$ - soil moisture, $P W P$ - permanent wilting point, $E T_{A}$ - actual evapotranspiration, $P E_{A}$ - potential evapotranspiration

10 The discharge response routine uses two storage compartments (reservoirs) and these compartments intend to describe the discharge behaviour of a catchment as direct runoff and groundwater outflow. Figure 4 gives an overview of the storage concept of the HBV-IWS model. More information about HBV-IWS can be found in Hundecha and Bárdossy (2004).

\section{Model setup}

HBV-IWS has two versions; a "grid based" and a "lumped" version. The "lumped" version is used in this study, dividing the study area into elevation bands with certain horizons. These elevation bands are the primary hydrological units and water balances are calculated for each. As a first step, the DEM was aggregated into a $1000 \mathrm{~m}$ spatial resolution from an $80 \mathrm{~m}$ spatial resolution using an ArcGIS desktop mapping tool to decrease the number of cells within the catchment. Further, all input parameters were calculated for each cell in the catchment based on their geographic locations and elevations. Potential evapotranspiration is an input to HBV-IWS and has to be estimated outside the model. The Hargreaves-Samani method (Hargreaves and Samani, 25 1985), developed at the Utah State University, was chosen for estimation of evapotranspiration, which is based on almost universally available data. Using this method, the
HESSD

3, 2209-2242, 2006

Hydrological modelling using globally available data

A. Gafurov et al.

\section{Title Page}

Abstract Introduction

Conclusions

Tables References Figures

14

4

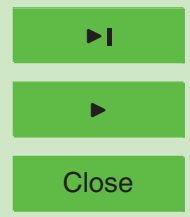

Full Screen / Esc

Printer-friendly Version

Interactive Discussion

EGU 
potential evapotranspiration is estimated for each cell of the catchment according to its geographic location.

In the next step, both catchments were subdivided into elevation bands (Neckar $100 \mathrm{~m}$ horizons and Chirchik $-200 \mathrm{~m}$ horizons). Once all the parameters for each

5 square grid were prepared, they were averaged for each sub catchment and for each zone (elevation band). Next, water balance calculations were carried out for each zone. The Neckar basin was subdivided into 59 subcatchments according to the gauging station availability whereas the Chirchik basin was subdivided into only 9 subcatchments due to the fewer gauging stations in the region. When the model is calibrated, it com10 putes the runoff of each subcatchment and passes it to the next downstream gauging station. Elevations in the Chirchik basin exceed $4000 \mathrm{~m}$ a.s.l.; in most cases glaciers exist above $3700 \mathrm{~m}$ a.s.I. in this region. For the regions above $3700 \mathrm{~m}$ a.s.l., a glacier module (described below) is therefore introduced.

\section{Calibration of the model for the Neckar Basin}

15 The HBV-IWS model was calibrated using 11 parameters through an automatic optimization algorithm called simulated annealing. The optimization was set up based on the accumulated flows of one month. The period from 1 January 1986 to 31 December 1994 was used for calibration to obtain parameter sets for each sub catchment in the Neckar basin. The model produced daily discharge values, but accumulated monthly discharges were compared against monthly observed data.

The correlation and explained variance are calculated to judge the performance of the model. During the first calibration, the explained variance was not good enough for small catchments whereas correlations of these catchments were acceptable. This means that the modelled and observed discharge curves have a similar shape but that the quantity of water in those discharges do not match. The reason for this is a scarceness of the data. For small catchments there is almost no variability in precipitation since one grid of the grid based precipitation distribution is much bigger than some

HESSD

3, 2209-2242, 2006

Hydrological modelling using globally available data

A. Gafurov et al.

Title Page

Abstract

Conclusions

Tables

Figures

14

4

Back

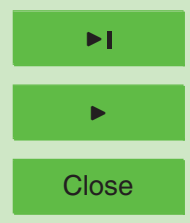

Full Screen / Esc

Printer-friendly Version

Interactive Discussion 
small catchments and this is also why precipitation is evenly distributed for some catchments. The performance of the model for larger catchments with a larger watershed area was reasonably good for the first run of the model. As a second step, in order to eliminate major errors from minor sub catchments the optimization was set to only 55 stations for large watershed areas. The calibration showed acceptable results for the Neckar basin. The performance of small catchments also suggests that the model works well enough, but that the input precipitation information is not able to represent the heterogeneity of the catchment as expected.

Monthly means give relatively reliable results. They are satisfactory, both in terms of 10 distribution and timing. Daily discharges also give a useful result in terms of distribution but the time of occurrence is not as pleasing. Daily flow distributions can be modelled using this method. Figure 8 is an example of daily modelled discharge plotted against daily observed discharge.

In addition, duration curves of modelled and observed discharges are compared.

Duration curves provide information about the statistical distribution of flows.

Figure 9 shows a realistic daily flow duration curve. There is a difference in low flow periods in the figure. This is due to the fact that the Neckar is a highly modified river and many stretches of the river are controlled to assure minimum water level for transportation purposes.

This is why the model output shows the discharge as it was in its natural state and therefore lower than the observed discharge. Comparisons of standard deviations also show how the results can be used for water management and planning purposes. Table 1 shows statistical moments computed using the daily discharges from five gauging stations for the calibration period.

\section{Model calibration for the Chirchik Basin}

The Chirchik catchment has a very different climatic and geographic situation to the Neckar basin. The elevation alone differs more than 3 times between Chirchik and
HESSD

3, 2209-2242, 2006

Hydrological modelling using globally available data

A. Gafurov et al.

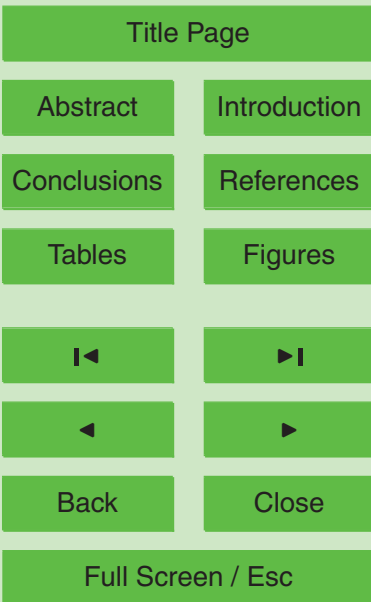

Printer-friendly Version

Interactive Discussion 
Neckar basin. Discharge in the Chirchik River is much larger in summer, when no rainfall occurs, than in winter. To be able to compute the discharge in the river for the summer season, long term snow and glacier melt has to be calculated which dominates the river flow in the summer.

5 To handle the different climatic and geographical conditions, the HBV-IWS hydrological model was modified to include a simulation for glacial behaviour. A glacier subroutine concept based on the degree day method was added. The whole Chirchik basin was subdivided into 17 elevation bands, whereby the 16th and 17th band are assumed to be covered by glaciers and the glacier module is only used in these regions. The 10 concept of the modified HBV-IWS model and the flowchart of the glacier subroutine are given in Figs. 10 and 11.

Two additional parameters are added for calibrating the glacier module; the threshold temperature for glaciers and the degree day factor for glaciers. During the calibration, the objective function was set to a monthly scale.

First results of the calibration for Chirchik showed an underestimation of modelled discharges compared to observation. The reason for this was found to be the underestimation of rainfall data from the disaggregation of GPCC global data. This is reasonable since GPCC only provides two data points for whole $15300 \mathrm{~km}^{2}$ Chirchik basin, with its catchment relief is very heterogeneous with many deep valleys. This is why

it is correct to assume that the rainfall distribution among the catchment is not similar to the observations. These data may have been observed from a lower region where less rainfall occurrences are recorded and taken as a representative of the surrounding area where totally different and much more rain could occur. For these reasons, the global data is found to have underestimated the rainfall data for this high mountainous 25 region. This could easily be seen from the model output (Fig. 12).

As can be seen from the graphs above, the correlation of observed and modelled discharge is relatively good. This shows that the flow dynamics are computed correctly but that there is bias that is assumed to be caused by the rainfall data. In order to check the bias, observed precipitation data at the Kyzilcha station (2085 m a.s.I.) was

\section{HESSD}

3, 2209-2242, 2006

\section{Hydrological modelling using globally available data}

A. Gafurov et al.

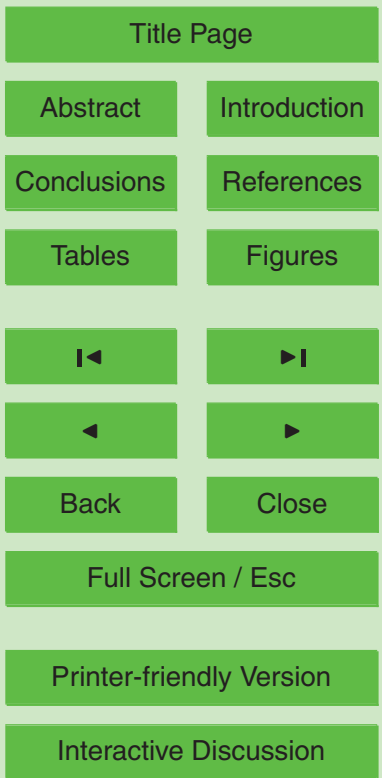


compared with the global data that was used in this study and the comparison provided a possible explanation for the model's underestimation of discharge (Fig. 13).

Figure 13 clearly shows that the rainfall data is underestimated by the global data service centres for very high mountainous regions and, in turn, why the model under5 estimates the discharge.

To get the more realistic distribution of rainfall data for a catchment like the Chirchik basin, a physical relationship for precipitation amount as a function of elevation could be investigated. The lapse rate method describes the temperature very well since a physical law behind temperature and elevation exists. Here, the lapse rate method is 10 tested for precipitation estimation at higher regions and compared with the available observed data. Since there is no standard lapse rate given for the precipitation, it was estimated using observed data obtained from globally available KNMI data. Using these station data at different elevations, a logarithmic relationship between elevation and precipitation was found and this change of precipitation was used as a rainfall 15 lapse rate for the correction of rainfall data for the upper Chirchik basin at each grid cell. The concept of lapse rate estimation for the region is illustrated in Fig. 14.

In Fig. 14, the relationship between precipitation and elevation is weaker than between temperature and elevation. This is due to the topography and the location of the observation stations. The Chirchik basin consists of many deep valleys and therefore data precipitation data from a particular observation point correspond to only the very local weather. In contrast, point temperature measurements are representative for a slightly larger surrounding area. Some points in Fig. 14 are located in a location where the rainfall is affected by the wind direction. Accordingly, the rainfall amount differs from the location to location. The logarithmic relationship is assumed to assess the

lapse rate more precisely. Using this rate, precipitation was re-distributed for the whole catchment area and was applied to the model. The model was then calibrated again without no further modification. Model performance with corrected precipitation was relatively good. Correlation of the observed and modelled discharge was high and the efficiency was also satisfactory. Results with the corrected rainfall data are illustrated
HESSD

3, 2209-2242, 2006

\section{A. Gafurov et al.}

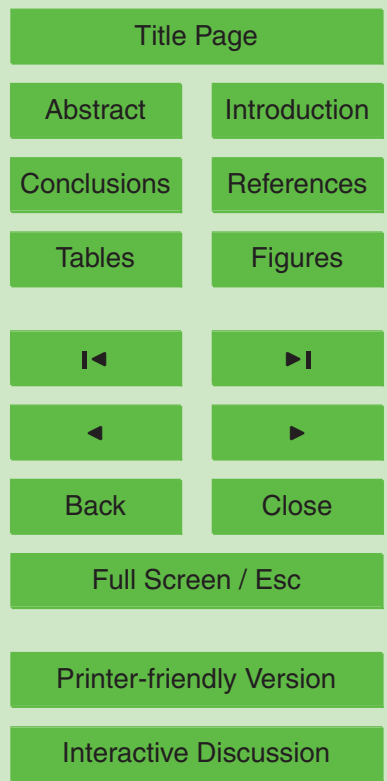

EGU 
in Figs. 15 and 16. They support the lapse rate method used for rainfall estimation in this study.

Daily observed discharge data was not available for Chirchik basin and therefore monthly average discharge values were used in the calibration. The model computes

5 daily discharges and accumulated monthly values are compared against observed data. Daily flow duration curves are not compared against daily observed discharge values since the observed data is not available. However, since the model computed daily discharges, it was still possible to plot flow duration curves of monthly discharge values. These show very good results and may be employed in water resources plan10 ning and management issues. The example given in Fig. 17 is the duration curve of monthly modelled discharge plotted against monthly observed data for the calibration period at the Chatkal station.

Since a good result for the monthly flow duration curve is achieved, it can be assumed that a reliable daily duration curve can be achieved, which can be used for 15 management and planning issues. The type of information computed above is of great significance in planning issues. For example, one could simply read off river characteristics from the plot e.g., when the flow is above or below a certain value.

\section{Conclusions}

Model results for the Neckar basin are very good considering the coarse data that was used in this research. Freely offered global data is based on grid cells and for small catchments, spatial variability may not necessarily be incorporated. This is why model performance for small sub catchments may not be as good as expected; due to precipitation uncertainty in small catchments. However, when modelling larger scales, global data are more realistic and the model has a relatively good performance. This was confirmed when the optimization was set to five main gauging stations with a large drainage area. In addition, model performance increased with the increase of drainage area.

HESSD

3, 2209-2242, 2006

Hydrological modelling using globally available data

A. Gafurov et al.

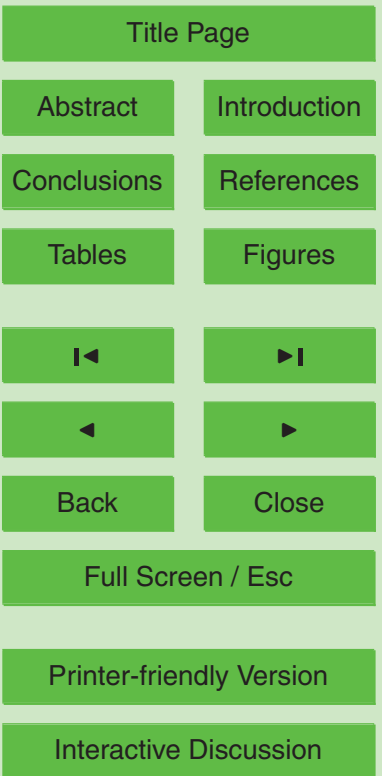

EGU 
Disaggregated precipitation data for the Chirchik basin resulted in underestimation due to uncertainties in the global data used for this region, particularly on account of the high elevations. The data from global databases was more successful in low-lying regions where observation stations were available. Using disaggregated data, the model 5 correlated observed and modelled discharges very well, however there was volume bias attributable to the rainfall underestimation. The lapse rate law for precipitation was also found to be suitable for such a region since the model calibration with corrected rainfall data gave very good results. In general, it can be said that the amount of rainfall increases with elevation.

10 Using this model, flow duration curves of the measured daily discharges can be reproduced accurately enough for management purposes. It would even be possible to use daily modelled discharges for many purposes since the duration curves of daily discharge in the Neckar basin gave good results. Given that the monthly duration flow duration curves proved to be relatively good in Chirchik basin, it is appropriate to assume that daily flow distributions also give reliable results. Using this method of modelling, daily distributions can be modelled, even if the exact timing is not very good. It is difficult to assume the discharge for a specific time span using this method, but overall daily distributions can be achieved accurately. For monthly scale modelling, the model is relatively good for both flow distribution and time representation. The study not only gives useful results for water resources management and planning issues but also shows the potential to model water balances in catchments where only globally available data is obtainable. Availability of more local observations in the catchments improves simulations and reliability significantly.

\section{References} ment and testing of the WaterGAP 2 global model of water use and availability, Hydrol. Sci. J., 48(3), 317-337, 2003.

HESSD

3, 2209-2242, 2006
Hydrological modelling using globally available data

A. Gafurov et al.

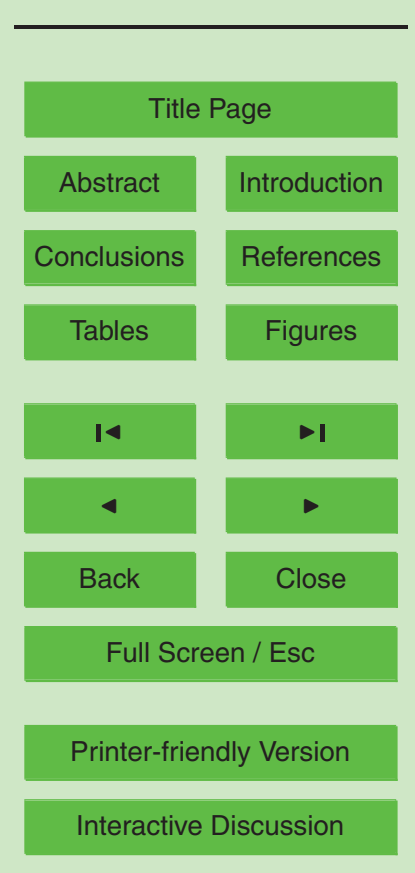


Alcamo, J., Heinrichs, T., and Rösch, T.: World Water in 2025 - Global Modelling and scenario analysis for the World Commission on Water for the 21st Century, Center for Environmental Systems Research, University of Kassel, Germany, 2000.

Falkenmark, M. and Lannerstad, M.: Consumptive water use to feed humanity - curing a blind spot, Hydrol. Earth Syst. Sci., 9, 15-28, 2005.

Hundecha, Y. and Bárdossy, A.: Modeling on the effect of land use changes on the runoff generation of a river basin through parameter regionalization of a watershed model, J. Hydrol., 292, 281-295, 2003.

Hargreaves, G. H. and Samani, Z. A.: Reference Crop Evapotranspiration from Temperature, Agricultural Engineering Department, Utah State University, Logan, 1985.

Lehner, B., Henrichs, T., Döll, P., and Alcamo, J.: EuroWasser - Model-based assessment of European water resources and hydrology in the face of global change, Kassel World Water Series 5, Center for Environmental Systems Research, University of Kassel, 2001.

Nelson, T. R. and Burtis, M.: The Global Historical Climatology Network - GHCN, Oak Ridge 15 National Laboratory, 1995.

Rudolf, B., Fuchs, T., Schneider, U., and Meyer-Christoffer, A.: Introduction of the Global Precipitation Climatology Centre (GPCC), Deutscher Wetterdienst, Offenbach a.M., Germany, 2003.

Sivapalan, M., Takeuchi, K., Franks, S. W., Gupta, V. K., Karambiri, H., Lakshmi, V., Liang, X., McDonell, J. J., Mendiondo, E. M., O'Connell, P. E., Oki, T., Pomeroy, J. W., Shertzer, D., Uhlenbrook, S., and Zehe, E.: IAHS Decade on Predictions in Ungauged Basins (PUB), 2003-2012: Shaping an exciting future for the hydrological sciences, Hydrol. Sci. J., 48(6), 857-880, 2003.

United States Geological Survey (USGS): Shuttle Radar Topography Mission (SRTM), 2003.

UNDP: Human Development Report 2003, Millennium Development Goals: A compact among nations to end human poverty, Oxford University Press, New York, 2003.

HESSD

3, 2209-2242, 2006

Hydrological modelling using globally available data

A. Gafurov et al.

Title Page

Abstract Introduction

Conclusions References

Tables Figures

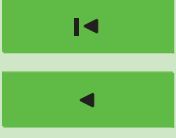

$\rightarrow$

Back

Close

Full Screen / Esc

Printer-friendly Version

Interactive Discussion 


\section{HESSD}

3, 2209-2242, 2006

\section{Hydrological modelling using globally available data}

Table 1. Statistical moments of observed and modelled discharges of 5 selected gauging stations in $\left(\mathrm{m}^{3} / \mathrm{s}\right)$.

\begin{tabular}{cccccc}
\hline Gauging Stations & \multicolumn{2}{c}{ Mean } & \multicolumn{2}{c}{ StDev } & Drainage Area $\left(\mathrm{km}^{2}\right)$ \\
\hline & Obs & Mod & Obs & Mod & \\
\hline Plochingen-Fils & 51.83 & 59.25 & 48.89 & 39.53 & 3723 \\
Vaihingen-Enz & 20.72 & 12.67 & 18.00 & 7.80 & 1653 \\
Elpershofen-Jagst & 17.51 & 19.53 & 20.88 & 20.36 & 1810 \\
Kocherstetten-Kocher & 24.80 & 24.98 & 28.56 & 17.34 & 1930 \\
Heidelberg-Neckar & 239.93 & 211.13 & 166.11 & 131.67 & 13300 \\
\hline
\end{tabular}
A. Gafurov et al.

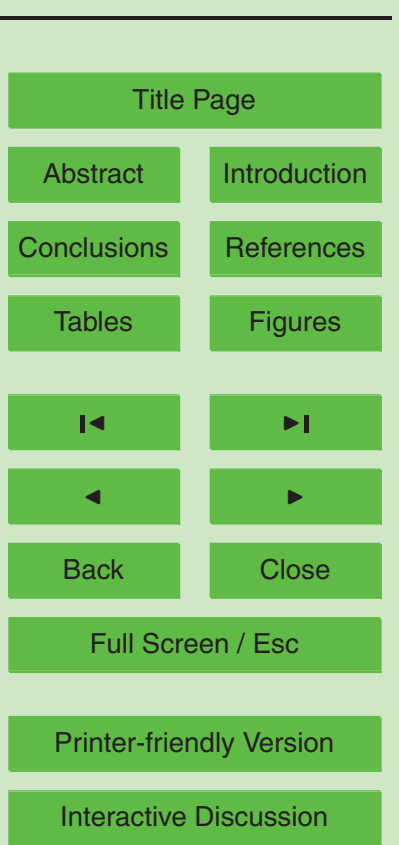




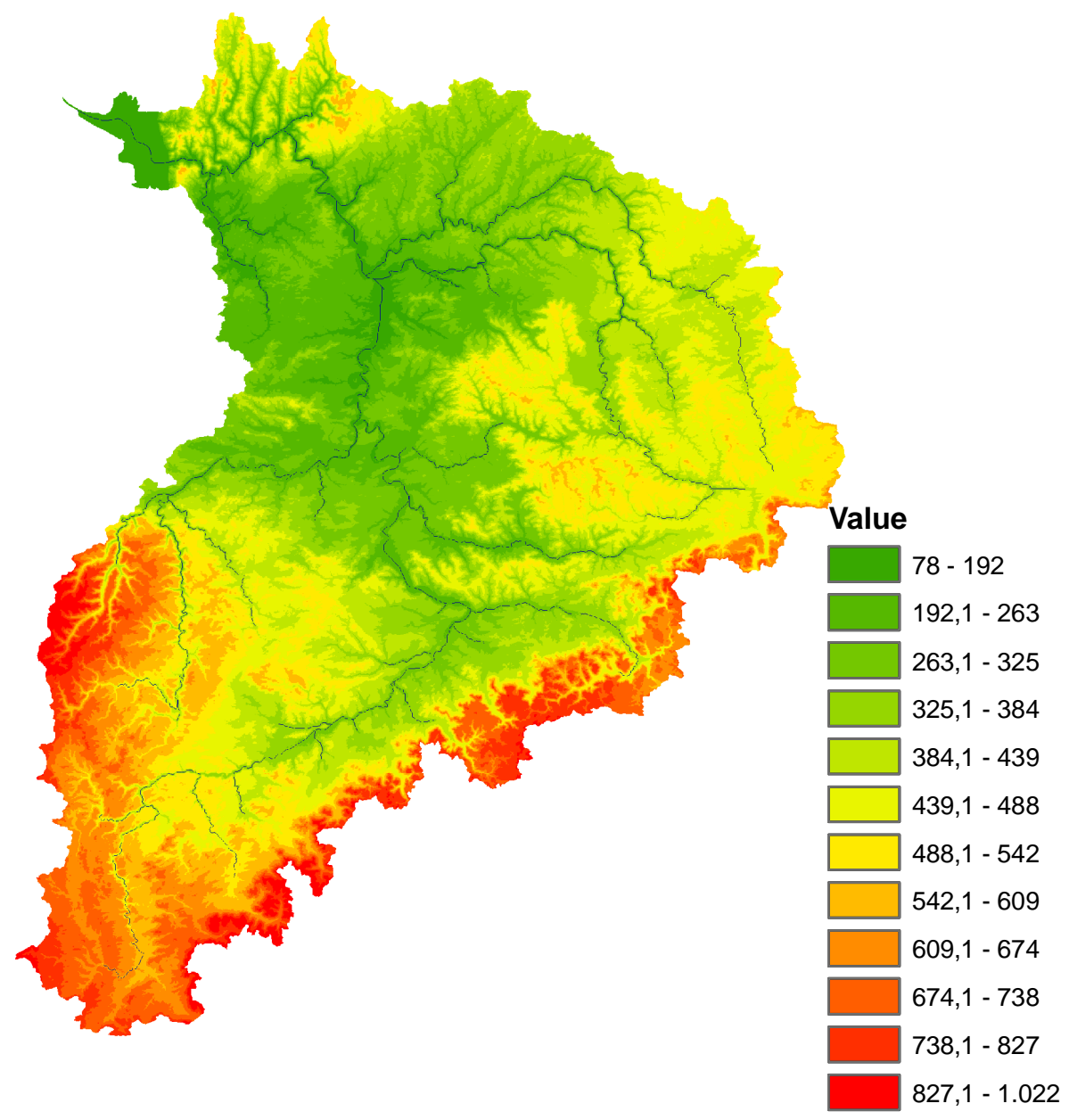

HESSD

3, 2209-2242, 2006

\section{Hydrological modelling using globally available data}
A. Gafurov et al.

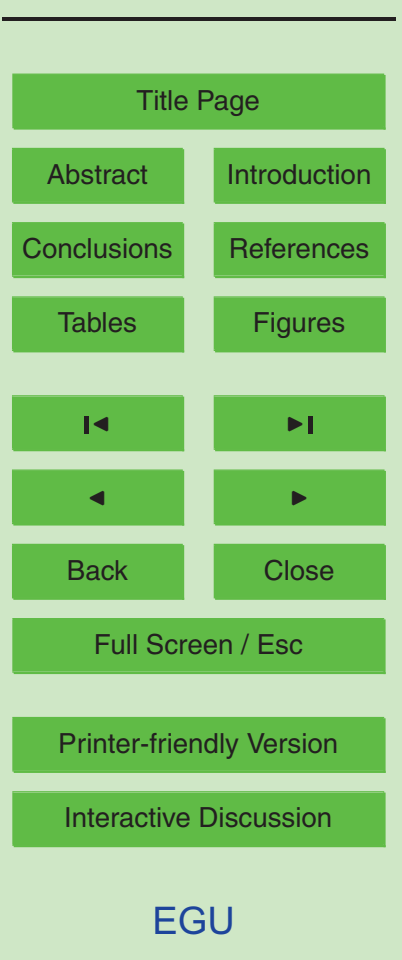




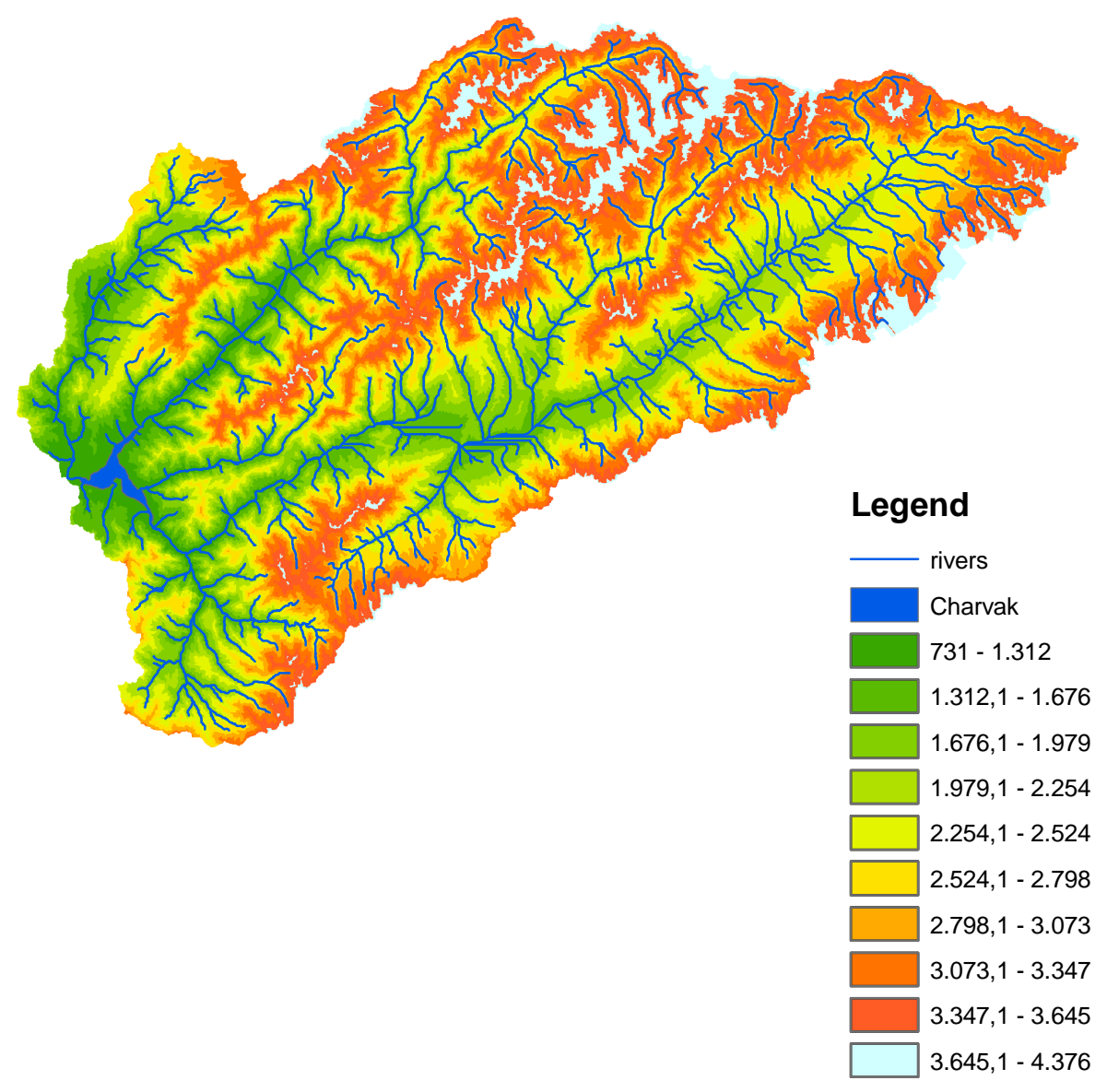

Fig. 2. Chirchik basin elevation map in Uzbekistan in $\mathrm{m}$ a.s.l.

\section{HESSD}

3, 2209-2242, 2006

\section{Hydrological modelling using globally available data}
A. Gafurov et al.

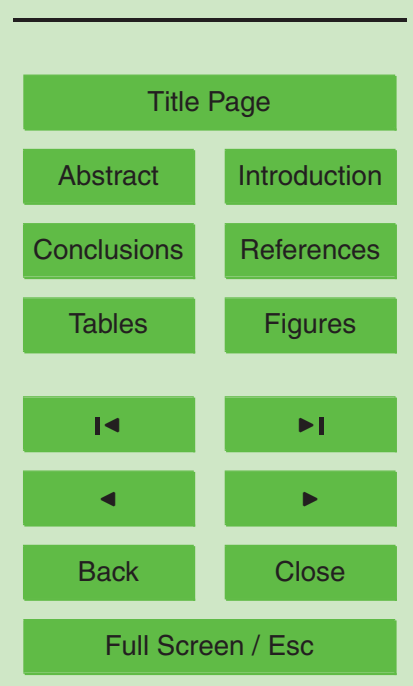

Printer-friendly Version

Interactive Discussion 


\section{HESSD}

3, 2209-2242, 2006

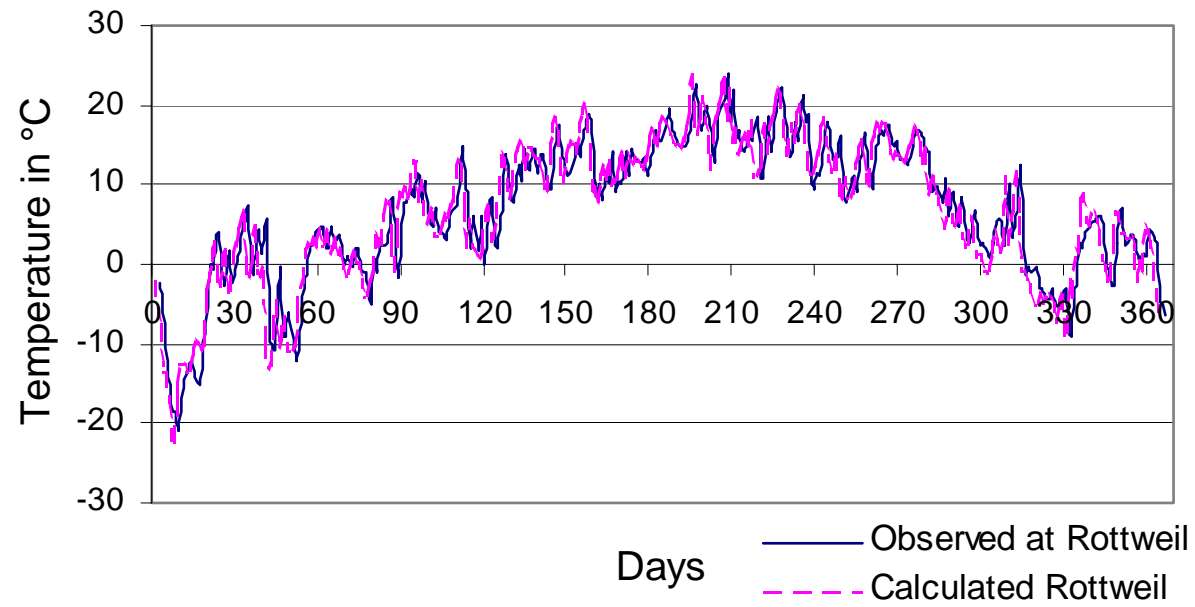

\section{Hydrological modelling using globally available data}
A. Gafurov et al.

Title Page

Abstract Introduction

Conclusions

References

Tables

Figures

14

$\rightarrow$ I

4

Back

Close

Full Screen / Esc

Printer-friendly Version

Interactive Discussion 


\section{HESSD}

3, 2209-2242, 2006

\section{Hydrological modelling using globally available data}

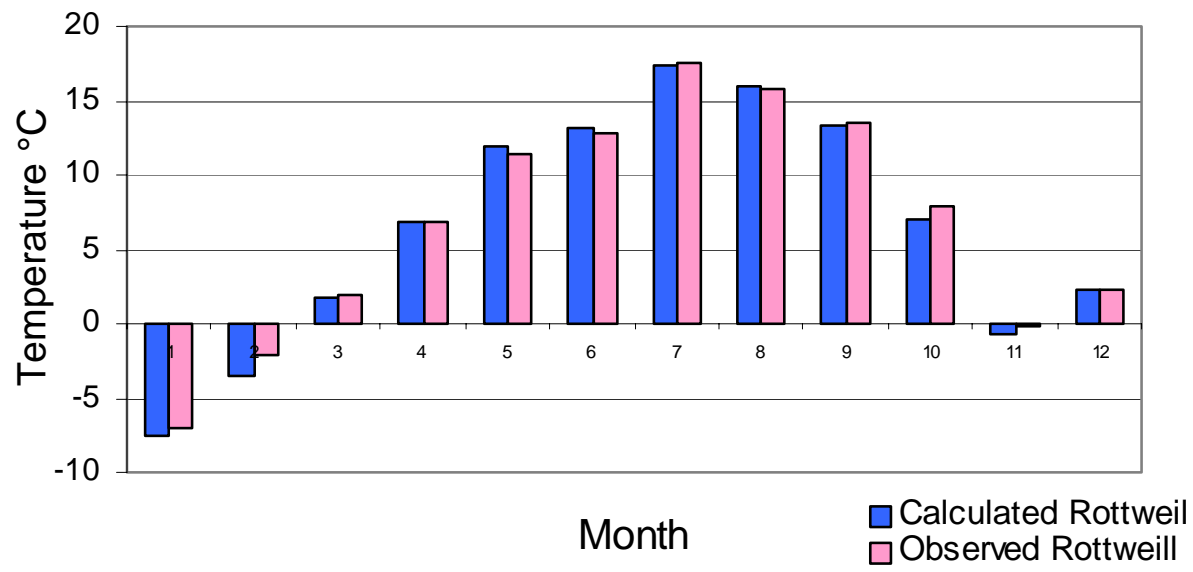

Fig. 4. Comparison of observed and calculated monthly temperature at Rottweil station.

Title Page

Abstract Introduction

Conclusions References

Tables Figures

14 $>$ I

4

Back

Close

Printer-friendly Version

Interactive Discussion 


\section{HESSD}

3, 2209-2242, 2006

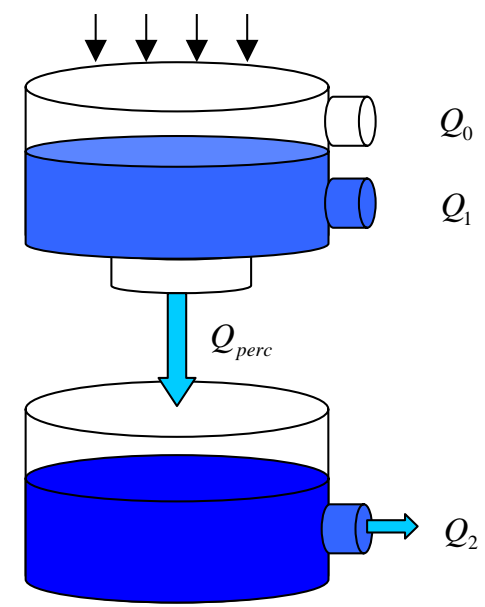

$$
\begin{aligned}
& Q_{0}= \begin{cases}0 & S_{1}<L \\
\frac{1}{k_{0}} \cdot\left(S_{1}-L\right) & S_{1}>L\end{cases} \\
& Q_{1}=\frac{1}{k_{1}} \cdot S_{1} \cdot \frac{A}{86.4} \\
& Q_{\text {perc }}=\frac{1}{k_{\text {perc }}} \cdot S_{1} \cdot \frac{A}{86.4} \\
& Q_{2}=\frac{1}{k_{2}} \cdot S_{2} \cdot \frac{A}{86.4} \\
& Q_{\text {tot }}=f(t, \text { Maxbas }) \cdot\left(Q_{0}+Q_{1}+Q_{2}\right)
\end{aligned}
$$

Fig. 5. Illustration of HBV discharge response routine.

\section{Hydrological modelling using globally available data}
A. Gafurov et al.

Title Page

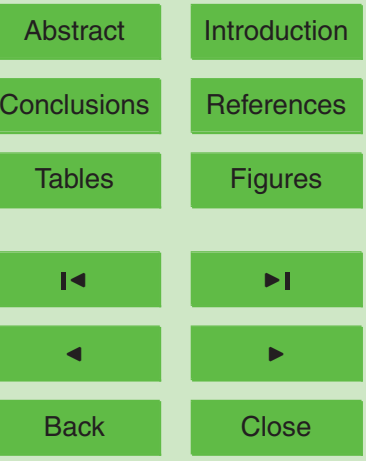

Full Screen / Esc

Printer-friendly Version

Interactive Discussion 


\section{HESSD}

3, 2209-2242, 2006

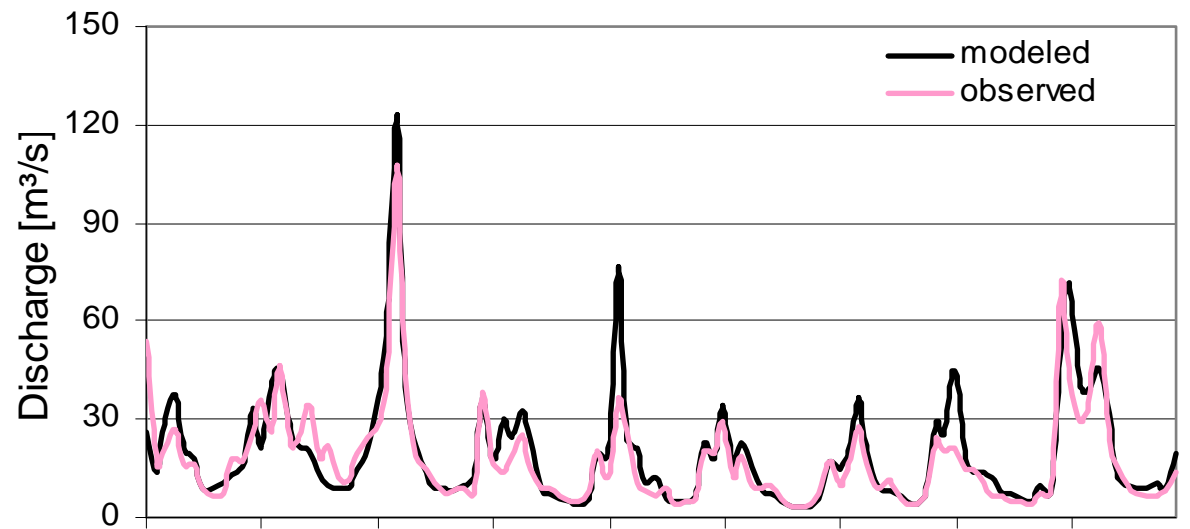

Jan-86 Jan-87 Jan-88 Jan-89 Jan-90 Jan-91 Jan-92 Jan-93 Jan-94

Time

Fig. 6. Monthly discharge comparison at Untergriesheim (calibration period).

\section{Hydrological modelling using globally available data}
A. Gafurov et al.

Title Page

Abstract

Introduction

Conclusions

References

Tables

Figures

14

- I

4

Back

Close

Full Screen / Esc

Printer-friendly Version

Interactive Discussion 


\section{HESSD}

3, 2209-2242, 2006

\section{Hydrological modelling using \\ globally available data}

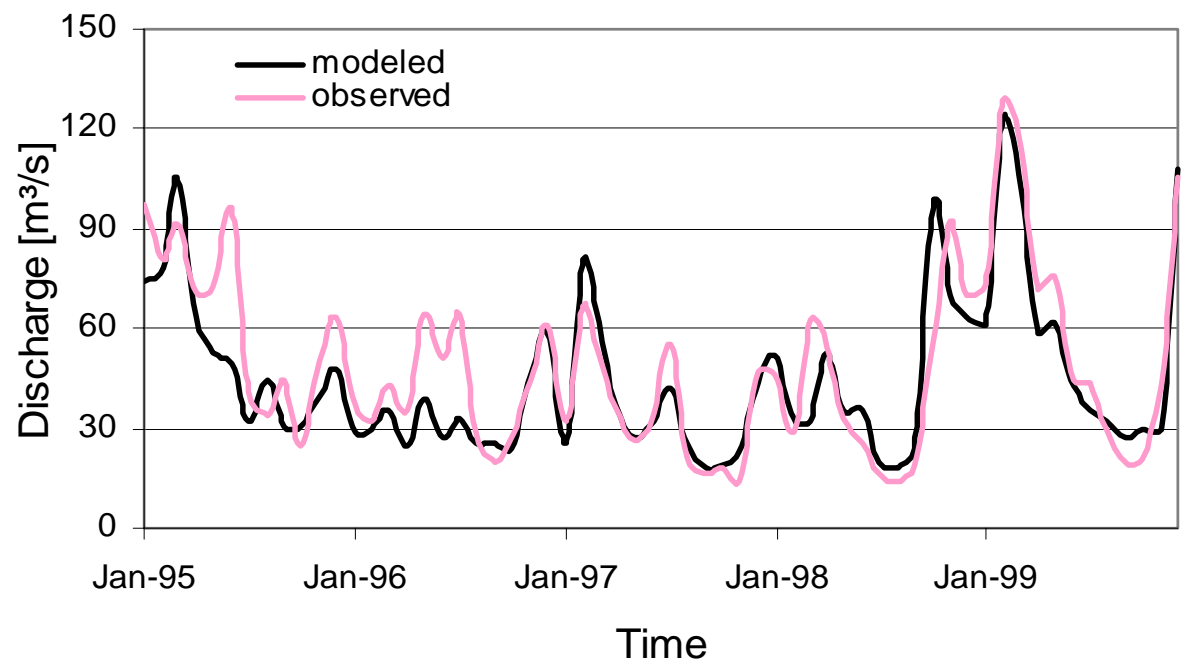

\section{A. Gafurov et al.}

Title Page

Abstract

Introduction

Conclusions

References

Tables

Figures

14

$\rightarrow$ I

4

Back

Close

Full Screen / Esc

Printer-friendly Version

Interactive Discussion 


\section{HESSD}

3, 2209-2242, 2006

\section{Hydrological modelling using globally available data}

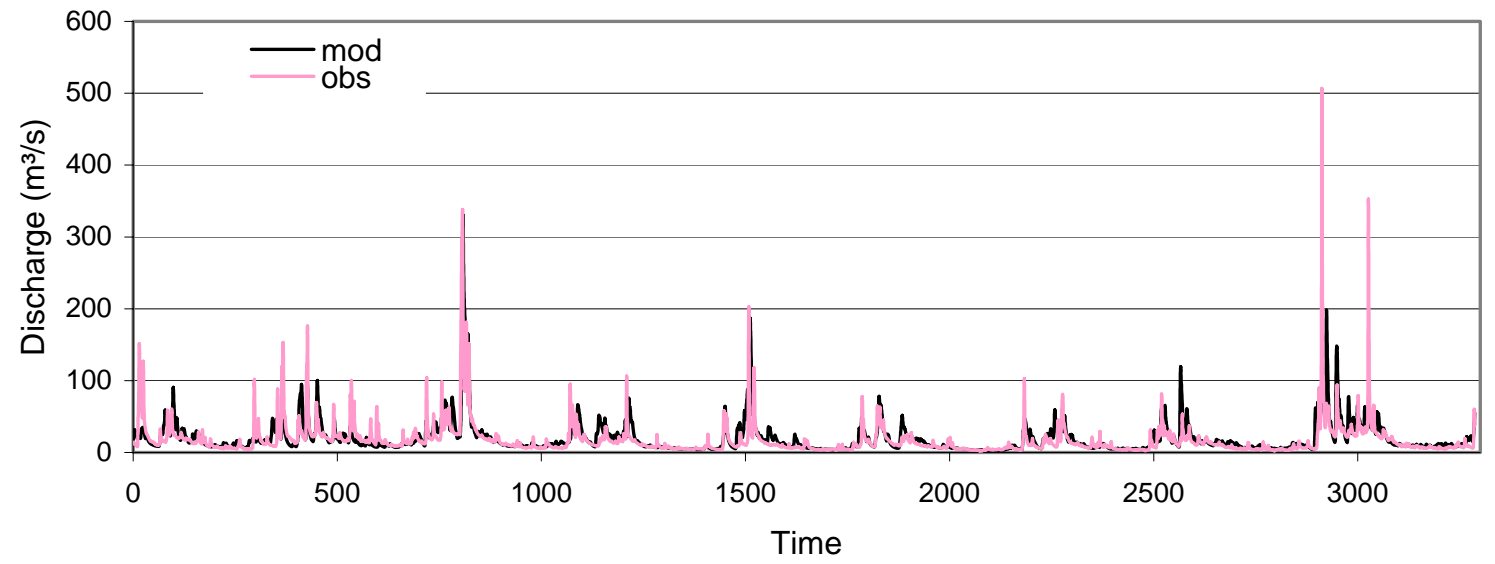

Fig. 8. Comparison of modeled and observed daily discharge at Untergrisheim-Jagst.
A. Gafurov et al.

Title Page

Abstract Introduction

Conclusions

References

Tables

Figures

14

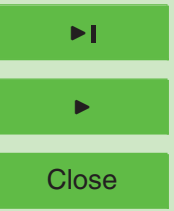

Back 


\section{HESSD}

3, 2209-2242, 2006

\section{Hydrological modelling using \\ globally available data}

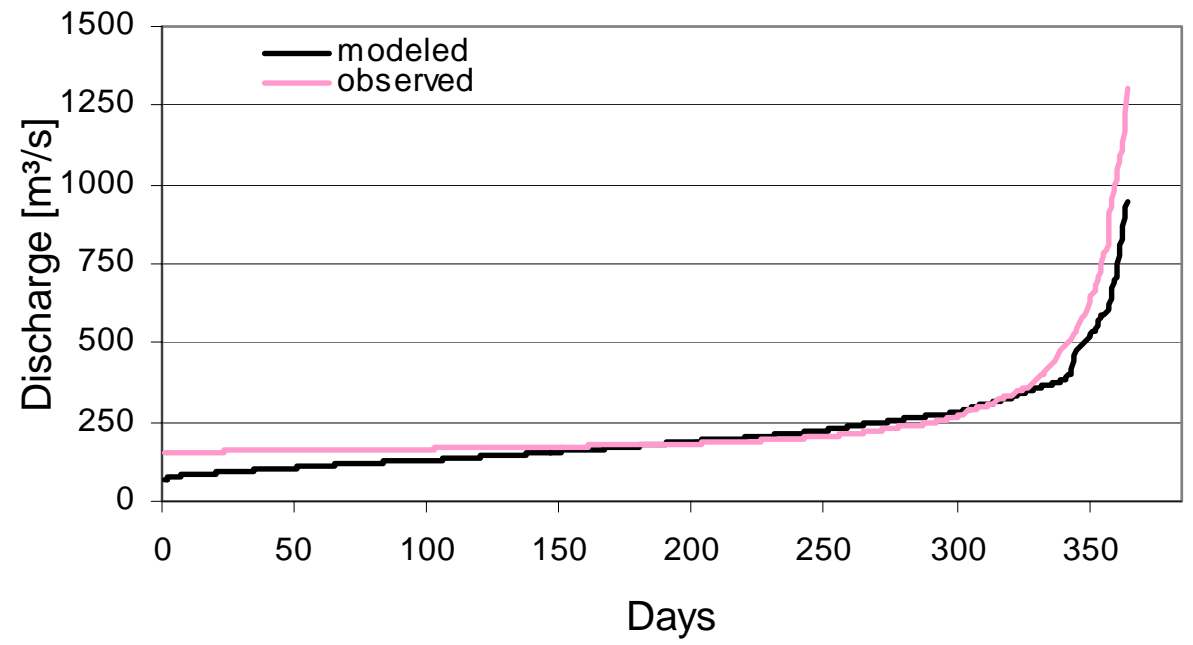
A. Gafurov et al.

Title Page

Abstract

Introduction

Conclusions

References

Tables

Figures

14

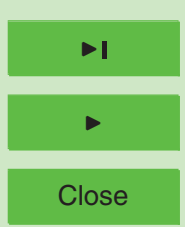

Back

Full Screen / Esc

Printer-friendly Version

Interactive Discussion 


\section{HESSD}

3, 2209-2242, 2006
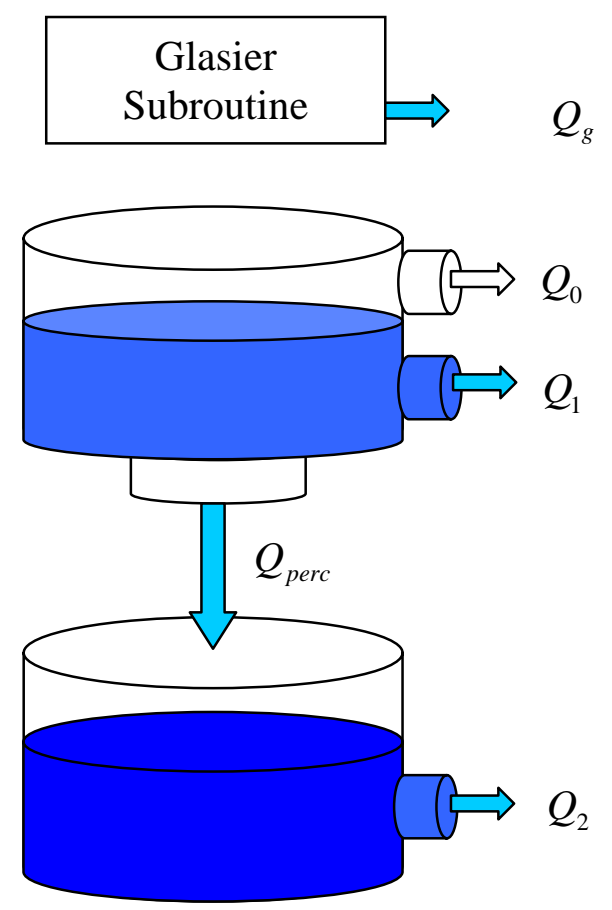

Fig. 10. Illustration of storage compartments in the modified version of HBV Model.

$Q_{g}$ - water coming from glacier melt, $Q_{0}$ - water leaving from upper outlet of upper reservoir, $Q_{1}$ - water leaving from lower outlet of upper reservoir, $Q_{\text {perc }}-$ water percolating from upper reservoir to lower reservoir, $Q_{2}-$ water leaving from lower reservoir.

\section{Hydrological modelling using globally available data}
A. Gafurov et al.

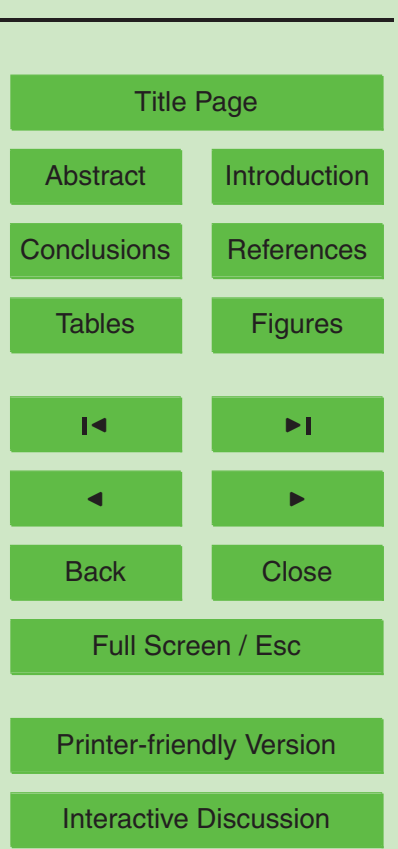




\section{HESSD}

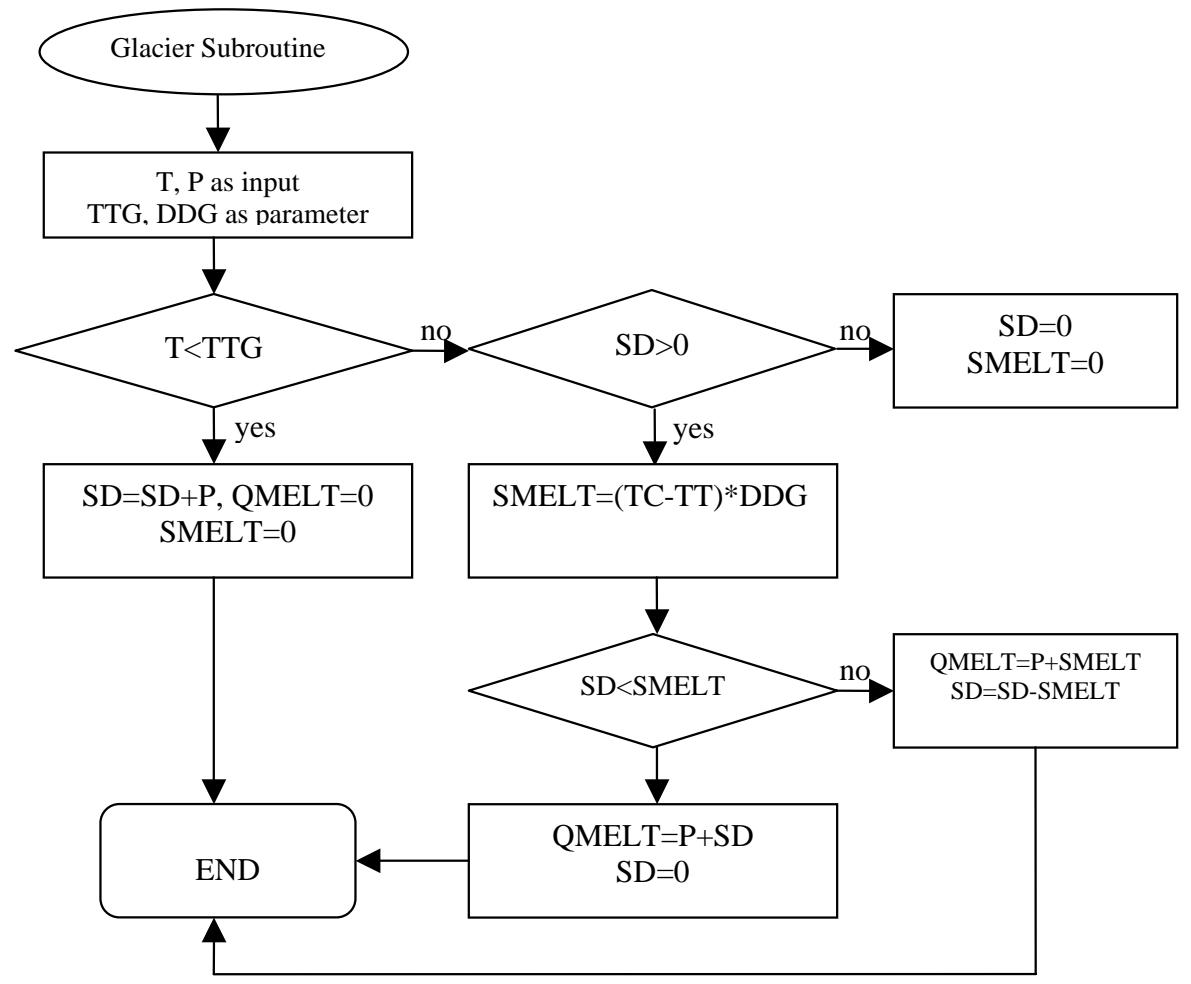

Fig. 11. Flowchart of the Glacier subroutine in HBV-IWS Model.

$\mathrm{T}$ - actual temperature $\left[{ }^{\circ} \mathrm{C}\right], \mathrm{P}$ - precipitation [mm], TTG - threshold temperature for glacier $\left[{ }^{\circ} \mathrm{C}\right]$, $\mathrm{DDG}$ - degree day factor for glacier [mm/ $/{ }^{\circ} \mathrm{C} /$ day], SD - snow depth [mm], QMELT - discharge from glacier melts [mm], SMELT - glacier melt amount [mm].
3, 2209-2242, 2006

\section{Hydrological modelling using globally available data}
A. Gafurov et al.

\section{Title Page}

\section{Abstract}

Introduction

Conclusions

References

Tables

Figures

14

4

Back

Full Screen / Esc

Printer-friendly Version

Interactive Discussion 


\section{HESSD}

3, 2209-2242, 2006

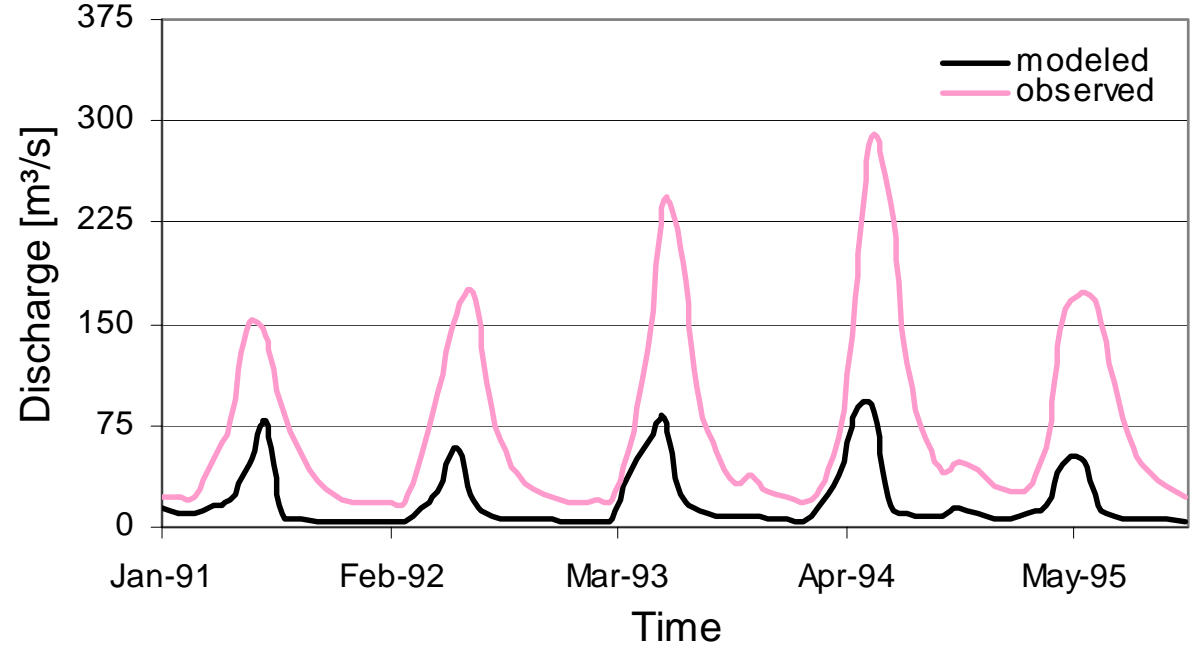

Fig. 12. Comparison of observed and modeled monthly discharge at Mullalla-Pskem without precipitation correction.

\section{Hydrological modelling using globally available data}
A. Gafurov et al.

Title Page

Abstract Introduction

Conclusions

References

Tables

Figures

14

$\rightarrow$ I

4

Back

Close

Full Screen / Esc

Printer-friendly Version

Interactive Discussion 


\section{HESSD}

3, 2209-2242, 2006

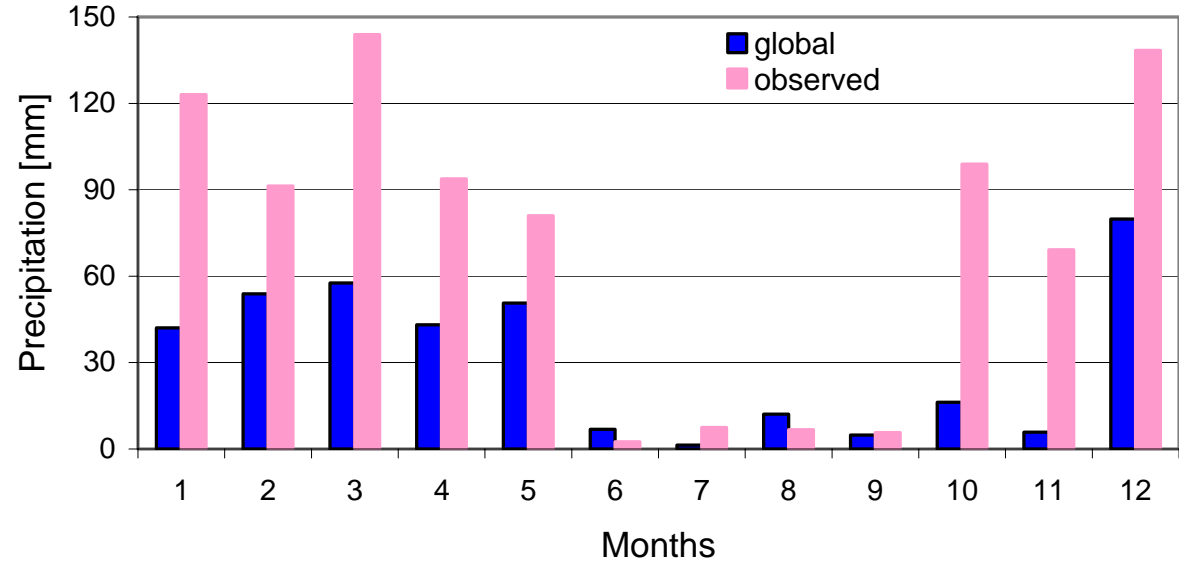

Fig. 13. Observed and modeled monthly precipitation comparison at Kyzilcha meteo-station for the year of 1988.

\section{Hydrological modelling using globally available data}

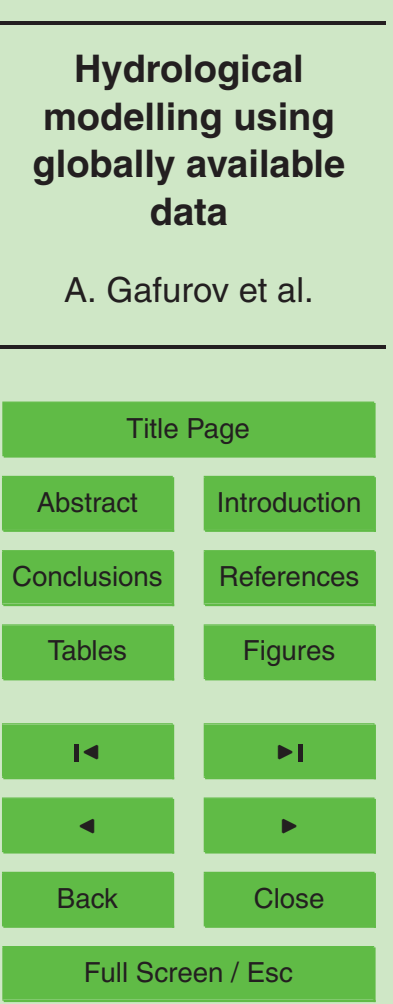

Printer-friendly Version

Interactive Discussion 


\section{HESSD}

3, 2209-2242, 2006

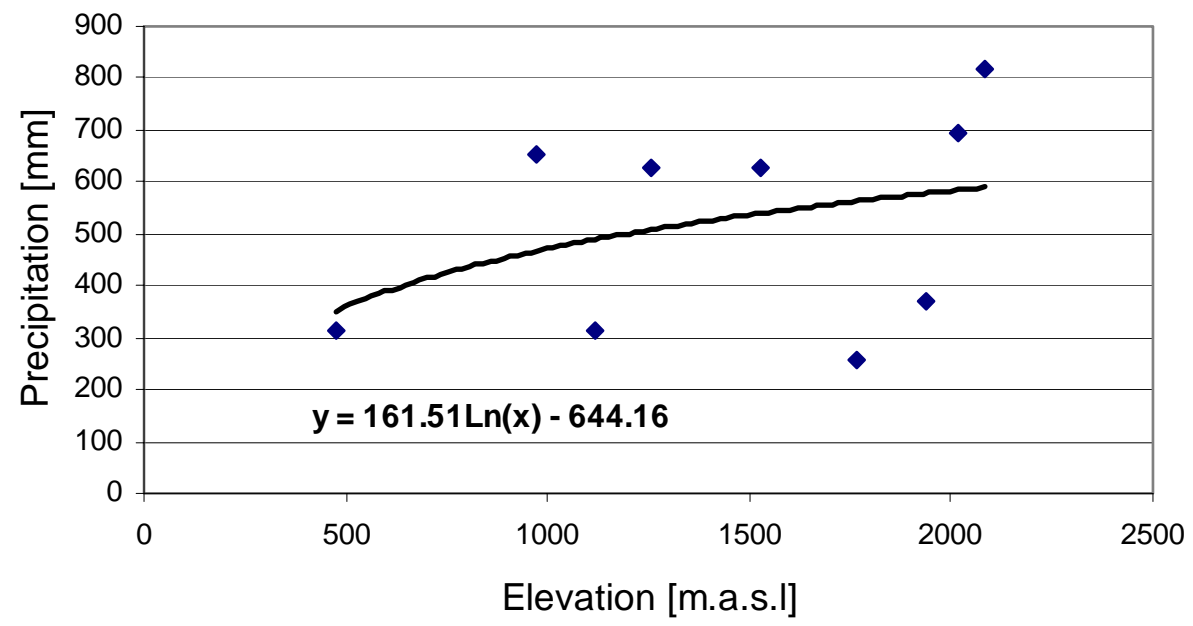

\section{Hydrological modelling using globally available data}
A. Gafurov et al.

\section{Title Page}

Abstract

Introduction

Conclusions

References

Tables

Figures

14

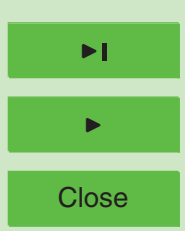

Back

Full Screen / Esc

Printer-friendly Version

Interactive Discussion

EGU 


\section{HESSD}

3, 2209-2242, 2006

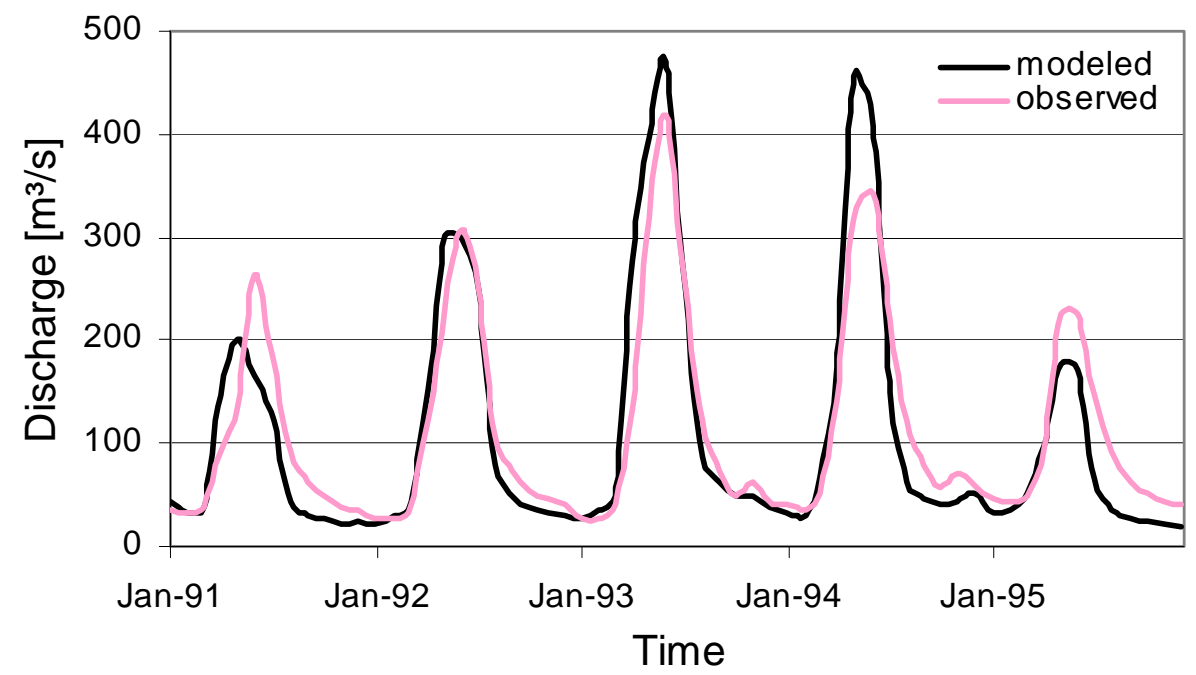

Fig. 15. Monthly discharge comparison at Hudaydodsoy with precipitation correction.

\section{Hydrological modelling using globally available data}
A. Gafurov et al.

Title Page

Abstract

Introduction

Conclusions

References

Tables

Figures

14

$\rightarrow$ I

4

Back

Close

Full Screen / Esc

Printer-friendly Version

Interactive Discussion 


\section{HESSD}

3, 2209-2242, 2006

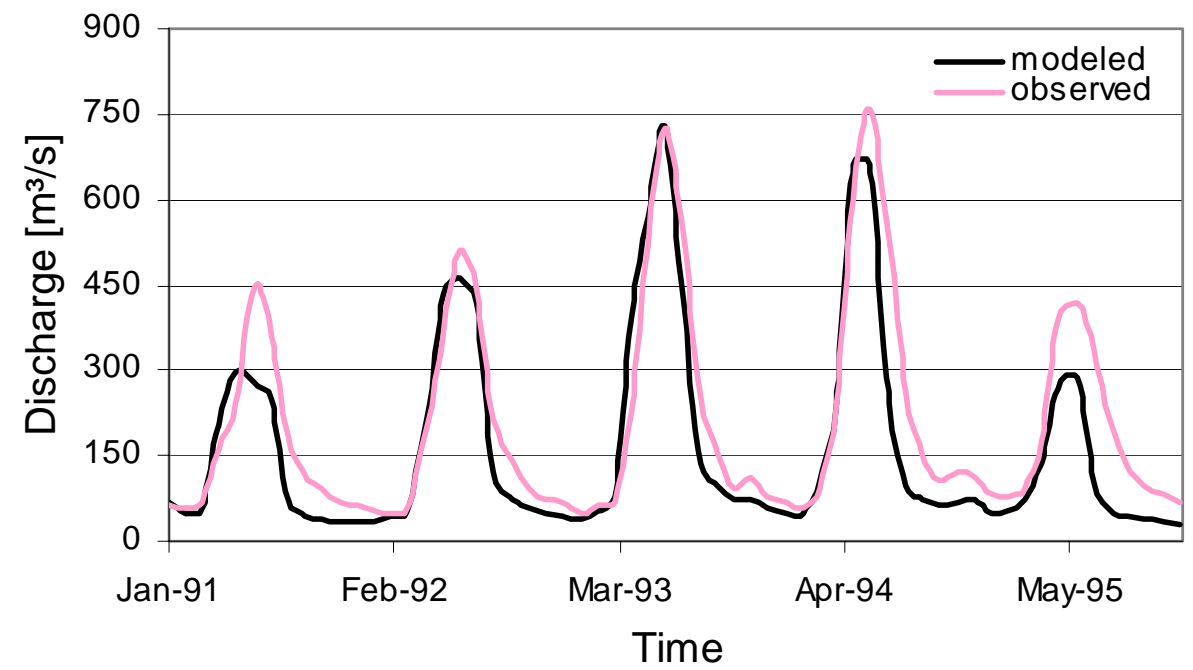

\section{Hydrological modelling using globally available data}
A. Gafurov et al.

Title Page

Abstract

Introduction

Conclusions

References

Tables

Figures

14

$\rightarrow$ I

4

Back

Close

Full Screen / Esc

Printer-friendly Version

Interactive Discussion 


\section{HESSD}

3, 2209-2242, 2006

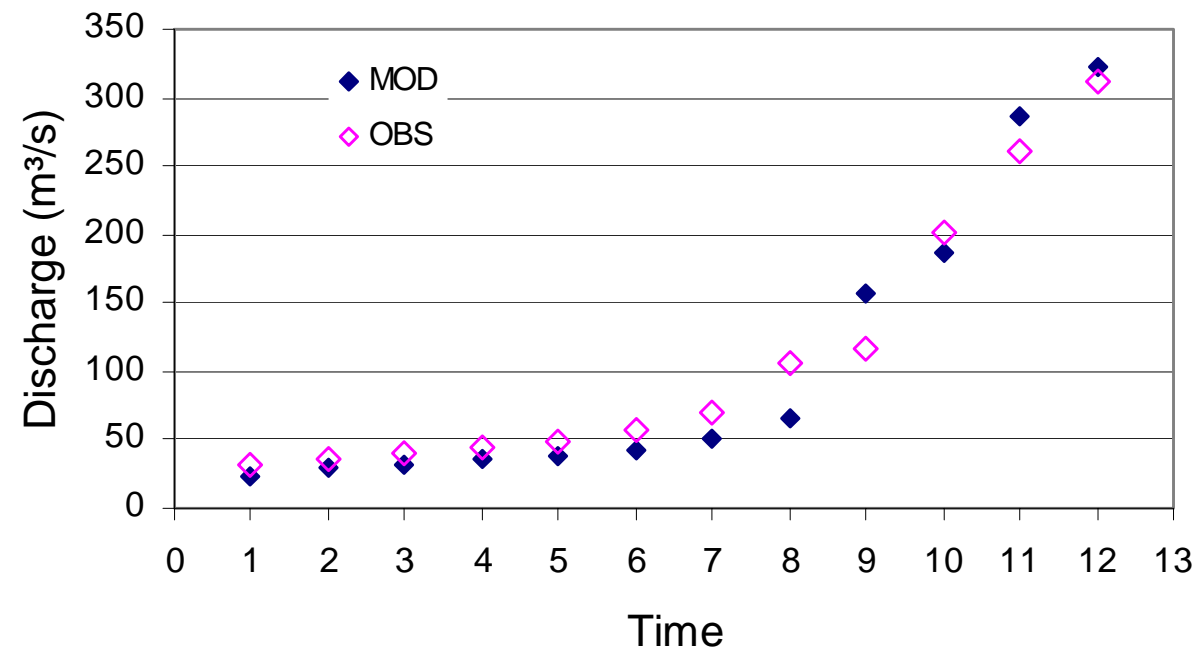

\section{Hydrological modelling using globally available data}
A. Gafurov et al.

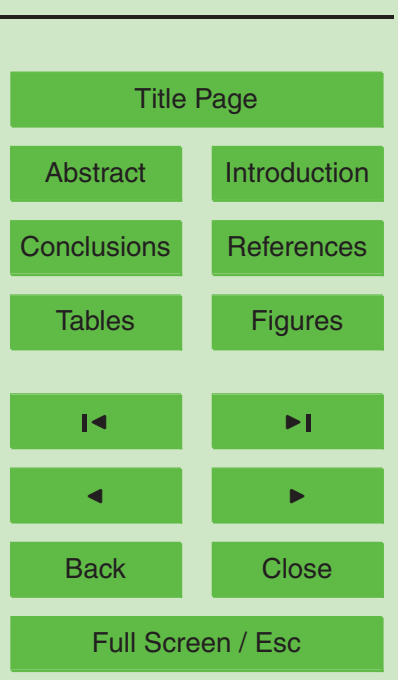

Printer-friendly Version

Interactive Discussion 


\section{HESSD}

3, 2209-2242, 2006

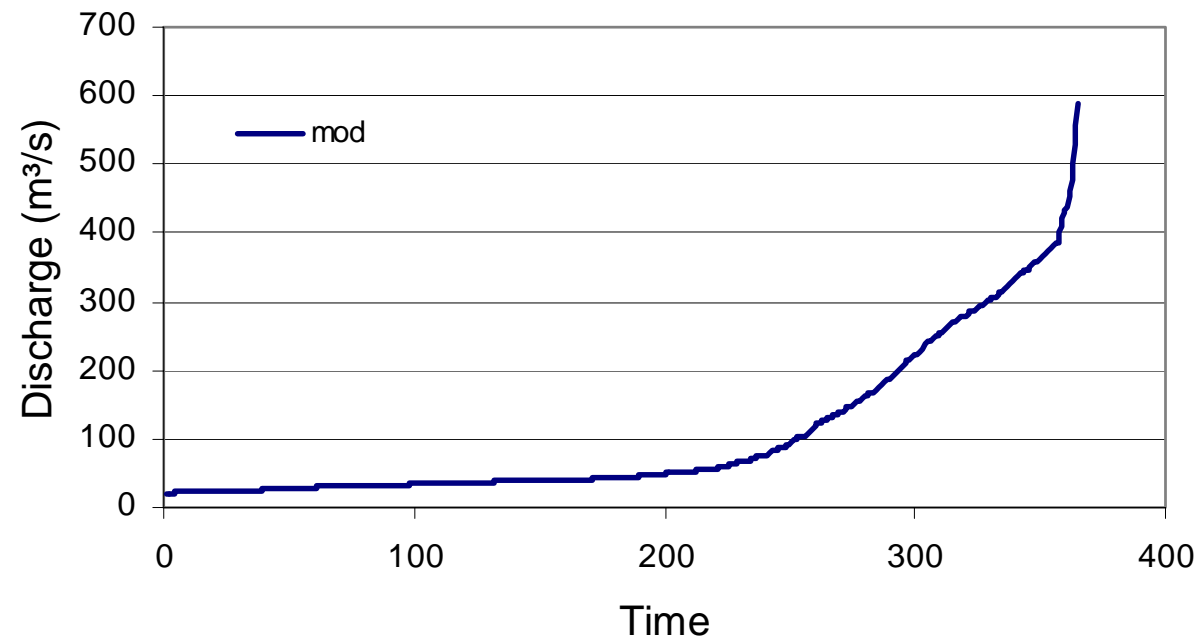

\section{Hydrological modelling using globally available data}
A. Gafurov et al.

Title Page

Abstract

Introduction

Conclusions

References

Tables

Figures

14

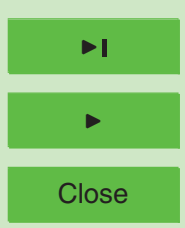

Back

Full Screen / Esc

Printer-friendly Version

Interactive Discussion 